\title{
AN UNCANNY LIFE
}

\author{
A man out of time.
}

\section{BY RYAN RUBAI}

$\mathrm{H}$ e has been here before. The stained peeling wallpaper, the dirt and debris marking the skirting boards are too unmistakable. Too real. He wonders if he should leave the room.

Opening the door, he plunges straight out into the abyss. It's pitch black but for a few puddles of bluishblack-like landing lights. A blinding headache engulfs him. He feels like he's being torn apart - ripped right down the middle, a real-life crease mark. Flashes of blue-tinged smoke erupt from the ether; crackling, hissing, screeching sounds come from nowhere and everywhere.

\section{Bang!}

He feels wetness trickling down the side of his head. The headache is gone. He's holding a gun. Gone. A subliminal from another time. He's in agony because he feels like this has happened already and it's like starting a film halfway through. He's on the floor but not on the floor. There's blood weeping from a head wound. There is no blood. There is no head wound. He's perfectly fine. Yet there he is, comatose on the floor with litres of blood pouring out. This is it, he thinks, the end of the line.

He is standing at the sink filling his coffee mug with water that froths over the sides. His foot bleeds. He cries out. He watches as his beard hair goes down the plug hole. The kettle boils. Shake twice, flush and wash. The cup slips out of his fingers.

It is evening now and he is sitting eating a microwaveable meal-for-one. He feels hungry and full at the same time and he can't figure out which one of him is the hungry one.

It was the first time he'd ever heard of it. Time Dissonance Syndrome. Reading from a medical dictionary, he found out that it was "a neurological disorder in which the patient perceives two or more similar but distinct lives simultaneously ... Dr Hans Müller and Professor Henry Bohr first hypothesized that TDS shares similarities with the déjà vu virus (page 127)... see their respective entries for more information".

He knew there was something wrong with

him when his father died. He was seven, in the backseat, his father hunched over the steering wheel and then time started to peel away, the inside of the car seemed to stretch. Then nothing. Just the sickening sound of metal on metal.

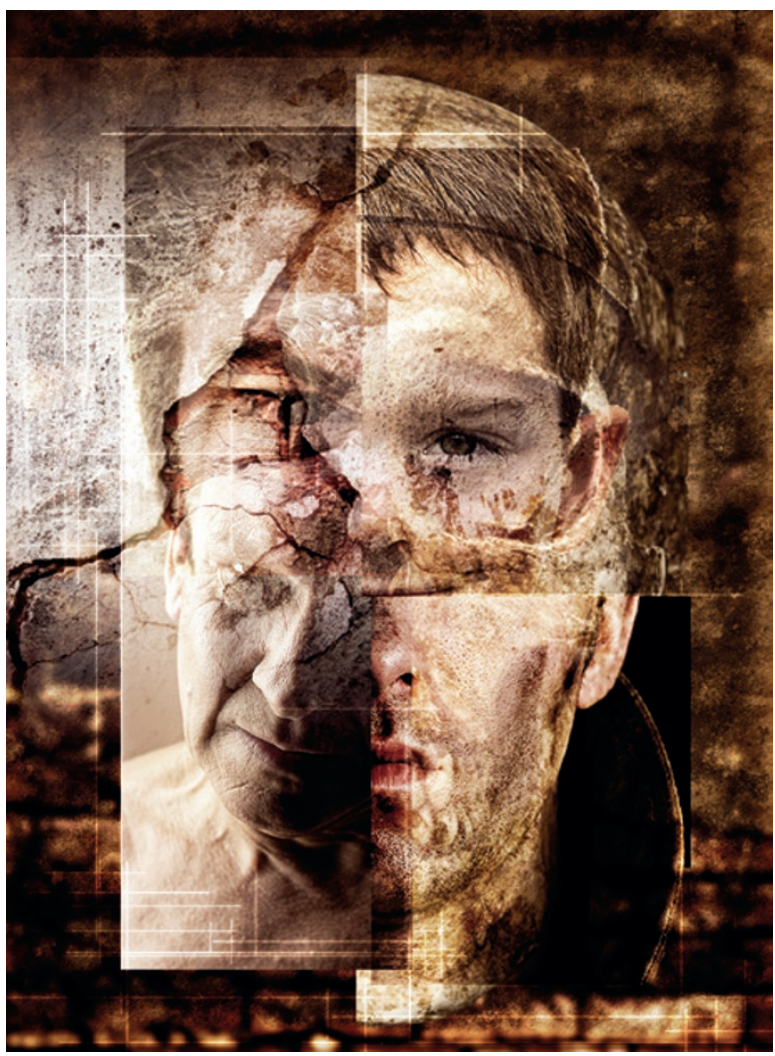

The terrible thing was he had never been in a car crash and his father was still alive.

Years later, after countless sessions with different psychiatrists and doctors he was finally diagnosed with Time Dissonance Syndrome. The doctors told him that it was common to have more timelines as a child. As he grew older, they said, these parallel timelines would diminish. He found it difficult to explain his problem to people. So he stopped trying.

Every moment, even in sleep, he feels like he is living more than one life.

\section{"You will experience some side effects." "Like what?"}

$\rightarrow$ NATURE.COM

Follow Futures: y @NatureFutures

$f$ go.nature.com/mtoodm
"Like ... your perception of time will alter. You'll perceive time on a nonlinear level without the notion of causality. The symptoms only last, on average, three weeks - but..."

"But what?"

"That's based upon lineal time, whereas we have no concrete idea of when you'll perceive the effects to stop."

They're laughing at him. In the playground, pointing their fingers and laughing. Daring themselves to go nearer and nearer. They tease him. Torment him with their name-calling, whispering behind his back.

The school has sent a letter home. Inattentive, they say. In a world of his own. His parents try to understand, try to see it from his point of view but he doesn't seem to hear. They take it the wrong way. "Can't you see that there's something wrong with the boy? This is your fault, you should have been firmer with him."

"Tom? Tom, are you listening? If you don't want to learn, then you can just leave the classroom." He is not paying attention. He is disconnected. He has been in this scene before.

In his bedroom, he's curled up into a ball, squeezing himself ever tighter. His mouth clenched, eyes like slits. The pain in his head is intense. He can feel liquid trickling down the side of his head. It's dripping off his earlobe like the last gasps of the water tap. The pain stops. As quickly as it came. He feels his head. Nothing there. He lies on his back, feels around. His hand touches something. He knows what it is, doesn't want to look at it, can feel the shape of it. Cold and harsh. He can feel the weight of it, the contours between his fingers. The feel of the trigger. It's all there. He looks down at his hand. Nothing there, nothing at all.

$\mathrm{He}$ is ten.

He has been here before. He desperately wants to catch up to some future version of himself and hope he can feel normal.

He has done it before. Felt the exploding headache that engulfs him. He has seen the smoke curl around the room.

He puts the gun up to his head.

\section{He has been here before.}

Ryan Rubai hails from Northern Ireland. He writes like he walks: a bit wobbly but he gets there in the end. He's also bad at writing bios. 